\title{
T-strain mycoplasma isolation and serology in women
}

\author{
RUTH B. KUNDSIN, ANGELES PARRENO, AND ANNA KIRSCH \\ Department of Surgery, Peter Bent Brigham Hospital, Boston, Massachusetts, U.S.A.
}

T-strains have been implicated in the aetiology of non-gonococcal urethritis in the male (Shepard, Alexander, Lunceford, and Campbell, 1964; Csonka, Williams, and Corse, 1966; Jansson, Lassus, Stubb, and Tuuri, 1971), in reproductive failure in women (Kundsin and Driscoll, 1970a, 1970b), and in low birth weights in infants (Braun, Lee, Klein, Marcy, Klein, Charles, Levy, and Kass, 1971). In most studies concerned with non-gonococcal urethritis in male patients, cultures have been taken only from those women known to be contacts. Csonka and others (1966) did extend their study to include control groups of women and reported the highest isolation rate of $\mathrm{T}$-strain mycoplasmas from urine of pregnant women, with a lower rate for non-pregnant women. The lowest isolation rates were in post-menopausal women and in young girls. Archer (1968), investigating the relationship between sexual activity and $\mathrm{T}$-strain colonization, reported more $\mathrm{T}$-strain isolations from sexually active women than from women who were sexually inactive.

This paper compares women with different life styles not only for rate of isolation of $T$-strain mycoplasmas from the urine, but for metabolic inhibition titres to $\mathrm{T}$-strain mycoplasmas as evidence of specific serological response to different $\mathrm{T}$-strain antigens. The presence of such titres indicates systemic response to an infection with $\mathrm{T}$-strains and would differentiate infection from colonization.

Two variables must be considered in any comparison of $\mathrm{T}$-strain isolation, namely the presence or absence of sexual activity, and the presence or absence of evidence of disease. The presence of the latter suggests infection or host response to an agent, but colonization by an organism may or may not lead to actual disease. The ideal population to serve as controls would therefore be a sexually inactive,

Received for publication September 23, 1972.

Supported in part by: The Massachusetts Division of Communicable Diseases, Dr. Nicholas Fiumara, U.S. Army Research and Development Command Grant DADA 17-69-C-9020.

Presented in part to: The American Society for Microbiology, Minneapolis, Minnesota, in May, 1971. asymptomatic group of individuals. It was possible to study such a group which could serve as an unassailable baseline for comparison for both these variables. We were most fortunate in securing the interest and collaboration of a teaching order of nuns in Massachusetts. Two visits one year apart were made to the convent.

The results from the sisters were compared with two populations of women whom we were studying concurrently.

One population consisted of affluent women who, because of reproductive abnormality, visited private obstetricians or gynaecologists but were otherwise asymptomatic. These women were considered sexually active but were assumed to be selective in their sexual contacts because they were anxious to initiate a successful pregnancy.

The other group was women with genito-urinary tract symptoms such as dysuria, frequency, or diffuse lower abdominal pain. They attended the genito-infectious disease clinic of the Peter Bent Brigham Hospital. This group consisted of young women, including college students and also some overt prostitutes. They were considered sexually active but not as family orientated and therefore not as selective in their sexual partners as the reproductive failure group.

\section{Material and methods}

A urine and a serum specimen were obtained from each participant. Each was asked to fill out a questionnaire regarding respiratory or genito-urinary tract infections within the past year. Information was also requested as to chemotherapy or antibiotic therapy. Several women who reported that they were on tetracycline therapy for a respiratory tract infection were excluded from the study. No perineal cleansing was done before collecting the specimen in a sterile container. Aliquots of urine were spun down in a clinical centrifuge for 10 minutes $(1790 \times$ G). The sediment was placed on A-3 medium appropriate for T-strains (Shepard, 1967) and Hayflick's medium for classical mycoplasmas (Hayflick, 1965). Both were 
grown using the Fortner plate technique (Fortner 1928). Sediment was also placed in U9 broth (Shepard and Lunceford, 1969) for colorimetric corroboration of $\mathrm{T}$-strain colonies visualized on the solid medium and on Thayer-Martin medium for gonococci. Blocks were carefully examined, using Dienes stain, of every culture for mycoplasma colonies on the Hayflick and Shepard media, at two magnifications $(\times 100$ and $\times 1,000)$, once at 3 days, and again at 1 week.

The metabolic inhibition test in microtitre was done according to the technique of Purcell, Taylor-Robinson, and Wong (1966).

Six antigens were used in the metabolic inhibition test (Table I):

TABLE I Source of antigens used in metabolic inhibition test

\begin{tabular}{|c|c|}
\hline Antigen & Source \\
\hline $\mathrm{K}-12$ & $\begin{array}{l}\text { From urethra of patient with non-gonococcal } \\
\text { urethritis (Shepard) }\end{array}$ \\
\hline Brown & $\begin{array}{l}\text { From cervix of symptomatic patient with genito- } \\
\text { infectious disease }\end{array}$ \\
\hline $\begin{array}{l}\text { Barbara } \\
\text { Ault }\end{array}$ & $\begin{array}{l}\text { From cervix of patient with carcinoma in situ } \\
\text { From cervix of patient with history of spontaneous } \\
\text { abortion }\end{array}$ \\
\hline $\begin{array}{l}\text { Nun } \\
\text { Boston T }\end{array}$ & $\begin{array}{l}\text { From urine of asymptomatic nun } \\
\text { From foetal membranes of middle trimester } \\
\text { spontaneous abortion }\end{array}$ \\
\hline
\end{tabular}

The antigens were chosen because of their diversity of source. All were cloned three times before use in the test.

\section{Results}

Three out of 93 ( 3 per cent.) nuns yielded mycoplasma isolates from the urine. Two were $T$-strains and one was $M$. hominis. The median age of the sisters participating in the study was 49 years. One from whom a $\mathrm{T}$-strain was isolated was 40 years old, the other 58 years old. The sister from whom M. hominis alone was isolated was 59 years old. It is particularly noteworthy that two of the sisters from whom mycoplasmas were isolated were postmenopausal. Only one isolate was made from nuns younger than 49 years. Metabolic inhibition tests to six antigens yielded one positive with $\mathrm{K}-12$ antigen and 48 with the Boston T-strain antigen.

The differences in the isolation of all mycoplasmas combined, as well as T-strains (Table II), were highly significant among the three groups $(P<0.001)$. The $\chi^{2}$ value (129) was highest for nuns compared with genito-infectious disease patients. The $\chi^{2}$ value (52) was lower but still highly significant in comparing the nuns and the reproductive failure group. The reproductive failure group compared with the genito-infectious disease group also achieved significance $\left(\chi^{2}, 22\right)$.
TABLE II Mycoplasma isolations from urine of women in three different categories

\begin{tabular}{|c|c|c|c|c|c|c|}
\hline \multirow{2}{*}{ Series } & \multicolumn{2}{|c|}{$\begin{array}{l}\text { Genito-infectious } \\
\text { disease }\end{array}$} & \multicolumn{2}{|c|}{$\begin{array}{l}\text { Reproductive } \\
\text { failure }\end{array}$} & \multicolumn{2}{|c|}{ Nuns } \\
\hline & No. & Per cent. & No. & Per cent. & No. & Per cent. \\
\hline $\begin{array}{l}\text { T-strains } \\
\text { T-strains and }\end{array}$ & 32 & 27 & 37 & 39 & 2 & 2 \\
\hline $\begin{array}{l}M . \text { hominis } \\
M \text {. hominis }\end{array}$ & $\begin{array}{r}64 \\
2\end{array}$ & $\begin{array}{r}53 \\
2\end{array}$ & $\begin{array}{r}11 \\
0\end{array}$ & $\begin{array}{r}12 \\
0\end{array}$ & $\begin{array}{l}0 \\
1\end{array}$ & $\begin{array}{l}0 \\
1\end{array}$ \\
\hline No mycoplasma & 22 & 18 & 46 & 49 & 90 & 97 \\
\hline $\begin{array}{l}\text { Total patients } \\
\text { tested }\end{array}$ & 120 & & 94 & & 93 & \\
\hline Mycoplasma & 98 & 82 & 48 & 51 & 3 & 3 \\
\hline $\begin{array}{l}\text { T-strain } \\
M . \text { hominis }\end{array}$ & $\begin{array}{l}96 \\
66\end{array}$ & $\begin{array}{l}80 \\
55\end{array}$ & $\begin{array}{l}48 \\
11\end{array}$ & $\begin{array}{l}51 \\
12\end{array}$ & $\begin{array}{l}2 \\
1\end{array}$ & $\begin{array}{l}2 \\
1\end{array}$ \\
\hline
\end{tabular}

$\mathbf{P}<.001$

T-strains were isolated alone from 27 per cent. of the genito-infectious disease group and from 39 per cent. of the reproductive failure group. $M$. hominis was isolated alone from only two patients ( 2 per cent.) in the genito-infectious disease group and never alone from the reproductive failure group. $M$. hominis has not been accepted as a cause of genito-urinary tract symptoms or reproductive abnormalities, although it might conceivably act as a symbiont with T-strains. The difference in the total isolation rate of $M$. hominis, whether alone or associated with T-strains, is statistically significant among the three groups. Csonka and others (1966) concluded that $M$. hominis could not be linked with non-gonococcal urethritis.

The reactive results with $T$-strain antigens using the metabolic inhibition test are compared in the three populations of women (Table III). Reactions to the Boston T-strain were highest in all three groups. However, differences between groups were statistically significant. The prevalence of positive metabolic inhibition titres to $T$-strain antigens paralleled $\mathrm{T}$-strain isolations; both were lowest in nuns, higher in the reproductive failure group, and highest in the genito-infectious disease group.

TABLE III Metabolic inhibition in three groups of women (percentage reactive)

\begin{tabular}{|c|c|c|c|c|c|c|}
\hline \multirow{2}{*}{ Group } & \multicolumn{2}{|l|}{ Nuns } & \multicolumn{2}{|c|}{$\begin{array}{l}\text { Reproductive } \\
\text { failure }\end{array}$} & \multicolumn{2}{|c|}{$\begin{array}{l}\text { Genito-infec- } \\
\text { tious } \\
\text { disease }\end{array}$} \\
\hline & No. & $\begin{array}{l}\text { Per } \\
\text { cent. }\end{array}$ & No. & $\begin{array}{l}\text { Per } \\
\text { cent. }\end{array}$ & No. & $\begin{array}{l}\text { Per } \\
\text { cent. }\end{array}$ \\
\hline $\begin{array}{l}\text { Antigen (1) K-12 } \\
\text { (2) Brown } \\
\text { (3) Barbara } \\
\text { (4) Ault } \\
\text { (5) Nun } \\
\text { (6) Boston T }\end{array}$ & $\begin{array}{r}1 / 103 \\
0 / 104 \\
0 / 101 \\
0 / 101 \\
0 / 101 \\
48 / 104\end{array}$ & $\begin{array}{r}1 \\
0 \\
0 \\
0 \\
0 \\
46\end{array}$ & $\begin{array}{r}5 / 42 \\
5 / 42 \\
3 / 41 \\
2 / 42 \\
2 / 39 \\
30 / 37\end{array}$ & $\begin{array}{r}12 \\
12 \\
7 \\
5 \\
5 \\
81\end{array}$ & $\begin{array}{r}12 / 56 \\
8 / 56 \\
7 / 53 \\
2 / 56 \\
2 / 55 \\
50 / 52\end{array}$ & $\begin{array}{r}21 \\
14 \\
13 \\
4 \\
4 \\
96\end{array}$ \\
\hline
\end{tabular}


The response seemed to fall into three patterns: the highest number were reactive with Boston $T$, an intermediate number with $\mathrm{K}-12$, Brown, and Barbara, and the lowest with Nun and Ault. When prevalence of reactive titres was ranked in all three groups, a high coefficient of concordance was found $(0 \cdot 78)$ indicating agreement in ranking as well as a highly significant Snedecor's F $(P<0.005)$ indicating a significance in the rank of prevalence of reactive titres (Moroney, 1953).

Gonococci were never isolated from the urines of the nuns or from the urines of the reproductive failure group. The genito-infectious disease group yielded Neisseria gonorrhoeae in 24 per cent. In only one patient was the gonococcus isolated alone. In the remaining patients from whom gonococci were isolated, they were found most frequently in combination with $\mathrm{T}$-strain mycoplasmas and $M$. hominis (17 per cent.), less frequently with $\mathrm{T}$-strains alone (6 per cent.), and only once with $M$. hominis alone.

\section{Discussion}

A comparison of $\mathrm{T}$-strain isolations from women reported by Archer (1968), Csonka and others (1966), and our results show similar patterns of relationship (Table IV). Eight of ten women with cervicitis or vaginitis had $\mathrm{T}$-strains. This agrees with our experience of an 80 per cent. isolation rate from 120 symptomatic women. Isolations from antenatal clinic patients ranged from 48 to 65 per cent. The lowest rates of isolation were from young girls and nuns.

Our observations further demonstrate that reactive metabolic inhibition tests with six $\mathrm{T}$-strain antigens follow the same pattern as the isolations in statistically significant numbers.

Isolation indicates colonization. The presence of reactive titres in the metabolic inhibition test in the same proportion as isolations indicates serological evidence of host response to $\mathrm{T}$-strain antigens. While it is postulated that circulating antibodies inhibit growth of T-strain mycoplasmas, the basis of the metabolic inhibition test, we are aware that some serum components also inhibit metabolism of T-strains. This is obvious with patients on tetracycline therapy. Other medications and perhaps hormonal factors influence the test. The converse is also true; i.e. some sera enhance the growth of T-strains. Shepard observed that urea in horse serum enhanced growth (Shepard and Lunceford, 1969). It is impossible to evaluate individual patient histories regarding enhancing or inhibiting factors that may be in the serum, as they may be nutritional, hormonal, or immunological. The comparison of
TABLE IV Percentage isolation of T-strain mycoplasmas from different groups of women (No. of cases in brackets)

\begin{tabular}{|c|c|c|c|}
\hline Group & Archer (1968) & $\begin{array}{l}\text { Csonka and } \\
\text { others (1966) }\end{array}$ & Kundșin \\
\hline $\begin{array}{l}\text { Genito-infectious } \\
\text { disease (cervicitis, } \\
\text { vaginitis) }\end{array}$ & - & $80 \% \quad(10)$ & $80^{\circ}{ }_{0} \quad(120)^{\mathrm{a}}$ \\
\hline Antenatal clinic & $58 \% \quad(100)^{\mathrm{a}}$ & $65 \% \quad(54)$ & $48^{\circ} \quad(50)^{b}$ \\
\hline Infertility clinic & $51 \% \quad(94)^{\mathrm{a}}$ & - & - \\
\hline $\begin{array}{l}\text { Reproductive } \\
\text { failure }\end{array}$ & - & - & $\begin{array}{l}\text { High risk } \\
\text { clinic } \\
67^{\circ}(54)^{\mathrm{b}} \\
\text { Private } \\
\text { patients } \\
51^{\circ} \quad(94)^{\mathrm{a}}\end{array}$ \\
\hline $\begin{array}{l}\text { Normal and } \\
\text { healthy (aged } \\
18-25 \text { years) }\end{array}$ & - & $40^{\circ} \quad(84)^{\mathrm{a}}$ & - \\
\hline $\begin{array}{l}\text { Girls } \\
\text { (aged 13-18 yrs) }\end{array}$ & - & $0 \% \quad(44)^{a}$ & - \\
\hline Nuns & $7 \cdot 6_{0}^{\circ}(105)^{\mathrm{a}}$ & - & $2 \% \quad(93)^{a}$ \\
\hline
\end{tabular}

reactive results obtained in the sera of the three groups is therefore noteworthy, as significant differences do exist in the three groups.

Differing findings regarding $T$-strain mycoplasmas and their role in salpingitis, genito-urinary tract infection, and reproductive abnormalities may be partly due to the method used for their isolation. $T$-strain mycoplasmas are extremely fastidious organisms, some strains more so than others. Dependence on subculture from a liquid medium, a fairly common practice (Braun and others, 1971), may be a reason for discrepancy. Hayflick and Stanbridge (1967) observed that 70 per cent. of mycoplasma isolations could not be subcultured. Initial isolation, they felt, was due to endogenous nutrients carried over from their natural environments. Some specimens may be frozen or refrigerated before culturing, another unknown factor influencing recovery. Foy, Kenny, Wentworth, Johnson, and Grayston (1970) used specimens frozen for 1 year and longer for primary isolation. The Fortner plate (Fortner, 1928) with Serratia marcescens on agar, adherent to the cover, provides a totally different microenvironment for growth from the 90-95 per cent. $\mathrm{N}_{2}$ and 5-10 per cent. $\mathrm{CO}_{2}$ used by Foy and others (1970) and Mårdh and Weström (1970).

\section{Summary}

The rate of isolation of $\mathrm{T}$-strain mycoplasmas from the urine was significantly lower in an order of 
teaching nuns than that from the urine of women with symptoms of genito-urinary infection and from asymptomatic women with a history of reproductive failure. Symptomatic sexually active women were colonized in significantly greater numbers than asymptomatic sexually active women and these in turn were colonized in significantly greater numbers than asymptomatic sexually inactive women. Metabolic inhibition tests to six T-strain antigens followed the same pattern as isolation of mycoplasmas, with fewer reactive in statistically significant numbers to $T$-strain antigens in nuns, a higher number in the reproductive failure group, and the highest number in women with genito-urinary symptoms.

If the metabolic inhibition test is a valid indicator of circulating antibodies, then sexual activity is directly related not only to $\mathrm{T}$-strain colonization, but also to $\mathrm{T}$-strain infection. sufficient to produce a systemic response.

\section{References}

ARCHER, J. F. (1968) Brit. F. vener. Dis., 44, 232

Braun, P., Lee, Y. H., Kiein, J. O., Marcy, S. M., Klein, T. A., Charles, D., Levy, P., and Kass, E. H. (1971) New Engl. F. Med., 284, 167

Csonka, G. W., Williams, R. E. O., and CoRse, J. (1966) Lancet, 1, 1292

FORTNER, J. (1928) Zbl. Bakt., 108, 155

FOY, H. M., KENNY, G. E., WENTWORTH, B. B., JOHNSON, W. L., and Grayston, J. T. (1970) Amer. F. Obstet. Gynec., 106, 635

Hayflick, L. (1965) Texas Rep. Biol. Med., 23 (Suppl. 1), 285

- and Stanbridge, E. (1967) Ann. N.Y. Acad. Sci. 143, 608

Jansson, E., Lassus, A., Stubb, S., and TuUri, S. (1971) Brit. F. vener. Dis., 47, 122

Kundsin, R. B., and DRIscoll, S. G. (1970a) Surg. Gynec. Obstet., 131, 89

- - (1970b) Ann. N.Y. Acad. Sci., 174, 794
MARDH, P. A., and WESTRÖM, L. (1970) Brit. F. vener. Dis. 46, 179

MORONEY, M. J. (1953) "Facts from Figures", 2nd ed., pp. 18, 134. Penguin Books, Harmondsworth, Middlesex

Purcell, R. H., Taylor-Robinson, D., and Wong, D. (1966) F. Bact., 92, 6

ShePARD, M. C. (1967) Ann. N.Y. Acad. Sci., 143, 505

-, AleXander, C. E., JR., LunCeford, C. D., and Campbell, P. E. (1964) f. Amer. med Ass, 188, 729

and Luncerord, C. D. (1969) Bact. Proc., 78.

Isolement de mycoplasmes de souches $\mathbf{T}$ sérologie et chez les femmes

SOMMAIRE

Le taux d'isolement de la souche $\mathrm{T}$ de mycoplasme dans l'urine fut significativement moins élevé dans un ordre de religieuses enseignantes que chez des femmes présentant des symptômes d'infection génito-urinaire et que chez des femmes sans symptôme mais avec antécédent de stérilité. Les femmes présentant des symptômes et ayant une vie sexuelle active eurent des cultures positives dans un nombre de cas significativement plus grand que les femmes asymptômatiques et sexuellement actives et, d'autre part, les résultats furent significativement plus grands que chez les femmes sexuellement inactives. Les tests métaboliques d'inhibition pour six antigènes de la souche $T$ se présentèrent comme les résultats de l'isolement des mycoplasmes avec, pour des antigènes de souche $T$, une positivité statistiquement significative plus faible pour les religieuses, un taux plus élevé pour le groupe des femmes stériles et le taux le plus élevé pour les femmes présentant des symptômes génito-urinaires.

$\mathrm{Si}$ le test d'inhibition métabolique est un indicateur valable des anticorps circulants, alors l'activité sexuelle est en relation directe non seulement avec la possibilité d'obtenir des cultures positives pour la souche $T$, mais aussi avec l'infection par la souche $T$, suffisante pour entraîner une réponse "systémique". 